\title{
IVO POSPIŠIL, НА ФОРПОСТАХ ТЕОРИИ И ИСТОРИИ КЛАССИЧЕСКОЙ РУССКОЙ ЛИТЕРАТУРЫ, SIEDLCЕ: INSTYTUT KULTURY REGIONALNEJ I BADAŃ LITERACKICH IM. FRANCISZKA KARPIŃSKIEGO. STOWARZYSZENIE 2015, $204 \mathrm{C}$.
}

В 2015 году в серии «Colloquia Litteraria Sedlcensia» (т. 20) была опубликована книга известного чешского исследователя - Иво Поспишила На форпостах теории и истории классической русской литературы. Как замечает сам автор, она представляет собой сборник избранных статей ученого, опубликованных между 2000 и 2011 гг. в чешских и иностранных научных издательствах. Лейтмотивом отдельных частей книги является тема классической русской литературы, вокруг которой ведутся исследования автора. Широкий и разнообразный охват материала, внимательный и глубоко профессиональный подход к исследуемой проблематике, ценные научные обобщения дают основание судить, что рецензируемая книга вполне достойна публикации в этой серии. Следует подчеркнуть, что существенным признаком некоторых студий, помещенных в сборнике, являются отзвуки русской классической литературы на чешской и моравской почве.

Первым, открывающим сборник текстом, является статья, посвященная проблемам эволюционной модели русской литературы. Автор пытается обосновать в ней мнение, касающееся того, что древнерусская литература возникла в результате восприятия чужих моделей и их трансформации, действующих как несовершенная имитация, и одновременно морфологическая инновация. Поспишил опирается здесь на взгляды Е. А. Ляцкого, С. Вилинского, В. Кожинова. Согласно этому русская литература XVIII века является лишь переходной стадией для новой, классической литературы. Возникновение новой литературы автор рассматривает на основе жанра романа, его имитационного, а затем оригинального этапов. Жаль, что в своих рассуждениях автор не взял во внимание более современных работ по русской литературе XVIII века, авторы которых имеют на нее другой взгляд, чем исследователи, приведенные в данной статье (ср. напр., работы Г. А. Гуковского, Ю. В. Манна, А. Н. Ужанкова, О. Б. Лебедевой, П. Е. Бухаркина).

Романтизм и проблема литературных жанров являются темой следующей статьи сборника. Автор, вслед за другими писателями и исследователями замечает, что романтизм - это некое общее направление, которое исторически не ограничено, но выступает как составная часть разных поэтик (панромантизм). Однако, учитывая существование литературных направлений и связанных с ними литературных жанров, ученый пишет, что эти 
последние изменяются под давлением литературных направлений и новой поэтики, а в качестве обратной связи влияют на структуру литературного направления. В качестве примера автор приводит жанр эпопеи и романа.

В следующей главе исследователь анализирует жанровую функцию мотивов сумасшествия в русской литературе XIX века. Определив сначала три основные модели сумасшествия в России этого столетия, автор переходит к их иллюстрации на примере произведений Пушкина, Погорельского и Лескова и приходит к выводу, что они все подходят к первой выделенной им модели - деструкции рациональности, рассудочного и морального устройства мира, оказавшегося под неожиданным экзистенциальным ударом. Исследователь однако подчеркивает, что у всех трех авторов мотивы сумасшествия служат жанровым катализатором, который формирует образования, выходящие за рамки литературы своей эпохи и содержащие «постмодернистскую» амбивалентность.

Глава Смерть ума, Россия и космическая поэзия посвящена теме сумасшествия в творчестве таких поэтов, как В. А. Жуковский, Е. А. Баратынский, Ф. И. Тютчев, М. Ю. Лермонтов. Тема «смерти ума» обнаруживает в поэзии этих авторов движение от напряжения к расслаблению, причем напряжение стремится к экстенсивности и поэтому крайне индивидуалистическая поэтика превращается в общую и космическую аморфность.

Под интригующим названием следующей студии - Романная одержимость камердинера Александра Пушкина находим текст, который посвящен экспериментам А. С. Пушкина в области жанра романа. И хотя, как подчеркивает автор, из-под его пера не вышел stricte роман, то все-таки его попытки создания этого жанра стали исходным пунктом золотого века русской литературы в общем и романа в особенности.

Очень интересной является, по-нашему, глава, посвященная чешской рецепции А. С. Пушкина. Автор приводит в ней мнения трех чешских филологов, историков литературы, переводчиков насчет великого русского поэта, его творчества и жизненных выборов (это: Франтишек Вымазал, А. Г. Стин и Франтишек Таборский). Их взгляды, как замечает исследователь, не нейтральные, они подчеркивают актуализацию творчества поэта и его понимание сквозь призму рецепции своего времени.

Две следующие главы связаны с Н. В. Гоголем. Первая из них, озаглавленная Творчество Гоголя в двойной проекции (к современным тенденциям гоголеведения), посвящена проблеме изучения творчества Гоголя в разные исторические времена. Автор замечает, что в противовес советскому времени сейчас Гоголь изучается разносторонне, многоаспектно, однако, по его мнению, бывший дуализм его видения нередко трансформируется во внеисторический дискурс и Гоголь оторван от русской, или точнее, восточнославянской культурной и религиозной традиции. Однако Поспишил добавляет, что есть и новые, компаративистские и документальные исследования, которые бросают на Гоголя новый, не только фактографический, но и методологический свет. 
Заканчивая, автор пишет, что современное гоголеведение представляет собой плюралистическую панораму, в которой целостность творчества писателя распадается на отдельные, как бы взаимно не связанные сферы и точки зрения.

Вторая, продолжающая гоголевскую тему глава, касается, в свою очередь, автохтонных и аллохтонных источников творчества Гоголя. Автор приходит к выводу, что на его характер имели влияние как восточнославянские, так и западноевропейские и античные традиции, которые жили в трансформированном виде в культурной среде семьи Гоголя и его самого.

Н. С. Лесков-это объект исследований автора в следующем разделе сборника. Поспишил обращает внимание, в том числе на язык и манеру повествования Лескова, его метод моделирования мира, способ представления дихотомии революционной демократии, теологии и самой литературы. Автор пишет также о жанровых попытках Лескова (журнальные заметки, сказ, историческая хроника, драматический тип романа), а также об образе праведника и образах иностранцев, которые встречаем в его произведениях.

В следующем разделе Поспишил подвергает анализу отзывы о смерти графа Л. Н. Толстого, которые появились в чешской культурной среде после смерти великого русского писателя, а также рассматривает общее положение русской литературы в Чехии в упомянутой культурной атмосфере.

В статье Исключительность романа Достоевского: миф или реальность? исследователь рассматривает значение романов писателя на чешской почве и основные научные труды чешских достоевсковедов.

Сборник заканчивается статьей под названием «Остров Сахалин» А. П. Чехова как лебединая песня русского классического романа и пути $\kappa$ новому роману, в которой автор рассматривает это произведение как пример заката русского классического романа.

Подытоживая, следует сказать, что включенные в сборник тексты (статьи) несомненно очень ценны как в тематическом, так и научном плане. Они вносят в науку о русской литературе очень интересные для всех занимающихся историей русской литературы факты и обобщения. Однако имея в виду то, что эти тексты были уже опубликованы в многоавторских монографиях, следовало бы лишить их некоторых повторений, а также унифицировать принципы их публикации (напр., присутствие или отсутствие списка литературы). Несмотря на эти замечания редакционного характера, рецензируемая книга Профессора Иво Поспишила очень полезна историкам русской литературы, студентам и всем, кто интересуется русской литературой.

\author{
Anna Warda \\ Uniwersytet Łódzki \\ Wydział Filologiczny \\ Instytut Rusycystyki \\ Zakład Literatury i Kultury Rosyjskiej \\ ul. Pomorska 171/173 \\ 90-236 Łódź \\ annawarda@uni.lodz.pl
}

